Pesq. Vet. Bras. 35(7):599-604, julho 2015

DOI: $10.1590 / \mathrm{S} 0100-736 X 2015000700001$

\title{
Accidental and experimental Closantel intoxication in Uruguayan sheep ${ }^{1}$
}

\author{
Rodolfo Rivero ${ }^{2 *}$, Carolina Matto ${ }^{2}$, Mauro Pereira Soares ${ }^{3}$ \\ and María de Lourdes Adrien ${ }^{4}$
}

\begin{abstract}
Rivero R., Matto C., Soares M.P. \& Adrien M.L. 2015. Accidental and experimental Closantel intoxication in Uruguayan sheep. Pesquisa Veterinária Brasileira 35(7):599-604. Laboratorio Regional Noroeste “Dr. Miguel C. Rubino", Dirección de Laboratorios Veterinarios of Ministerio de Ganaderia, Agricultura y Pesca, Ruta 3, Km 369, Cx. Postal 57.037, CP 60.000, Paysandú, Uruguay.E-mail: rrivero@mgap.gub.uy

An outbreak of Closantel intoxication in sheep in Uruguay is described. The outbreak occurred in a group of 1300 weaning lambs treated orally with a $10 \%$ solution of Closantel. One hundred forty eight lambs showed clinical signs of intoxication and 14 died. The clinical signs included mydriasis, nystagmus, and negative pupillary reflex, bilateral blindness, bump into objects, and lateral movement of the head. No macroscopic lesions were observed. The histological lesions of the retina were cytoplasmic vacuolization in ganglion cells and in cells of the inner and outer nuclear layers with different degrees of atrophy. Vacuolization and axonal degeneration were observed in the optic nerve, with multifocal areas of fibrosis and infiltration by lymphocytes and Gitter cells. To reproduce the intoxication, four sheep were given two, four and 10 times the therapeutic dose of Closantel $(0.1 \mathrm{~g} /$ $\mathrm{kg}$ of BW). Only the animals receiving 10 times the recommended dose showed clinical signs. The histological examination of the lesions in experimental sheep showed similar results to those described in the accidental outbreak, except for the absence of optic nerve fibrosis and inflammation, characterizing an acute phase. Axonal myelin sheaths loss, fibroblasts and collagen fibers were observed in the ultrastructural study of the optic nerve of accidental intoxicated animals. The optic nerve of experimentally intoxicated animals had vacuoles that separated the myelin sheaths of axons. To prevent outbreaks it is suggested to weigh the animals before Closantel administration to avoid errors in dose calculation.
\end{abstract}

INDEX TERMS: Closantel, antiparasitic overdose, poisoning, blindness, sheep.

RESUMO.- [Intoxicação acidental e experimental por Closantel em ovinos no Uruguai.] Descreve-se um surto de intoxicação por Closantel em ovinos no Uruguai. 0 surto ocorreu em um lote de 1300 cordeiros que foram dosados

\footnotetext{
${ }^{1}$ Received on December 3, 2014.

Accepted for publication on June 1, 2015.

${ }^{2}$ Laboratorio Regional Noroeste “Dr. Miguel C. Rubino”, Dirección de Laboratorios Veterinarios, Ministerio de Ganaderia, Agricultura y Pesca, Ruta 3, Km 369, Cx. Postal 57.037, CP 60.000, Paysandú, Uruguay. *Corresponding author: rrivero@mgap.gub.uy

${ }^{3}$ Laboratório Regional de Diagnóstico, Faculdade de Veterinária (FV), Universidade Federal de Pelotas (UFPel), Campus Universitário s/n, Pelotas, RS 96015-560, Brazil.

${ }^{4}$ Departamento de Salud en los Sistemas Pecuarios, Facultad de Veterinaria, Universidad de la República, Ruta 3 Km 363, CP 60.000, Paysandú, Uruguay.
}

com uma solução de Closantel 10\%, por via oral. Do total, 148 apresentaram sinais clínicos de intoxicação e 14 morreram. Os sinais clínicos incluíam midríase, nistagmo, reflexo pupilar negativo, cegueira bilateral, pressão da cabeça contra objetos e desvio lateral da cabeça. Lesões macroscópicas não foram observadas. Histologicamente havia vacuolização citoplasmática das células ganglionares e nas células das camadas nuclear interna e externa. Na retina havia, também, diferentes graus de atrofia. Vacuolização e degeneração axonal foram observados no nervo óptico, com áreas multifocais de fibrose e infiltrado de linfócitos e células Gitter. Quatro ovinos receberam experimentalmente duas, quatro e 10 vezes a dose terapêutica de Closantel $(0,1 \mathrm{~g} / \mathrm{kg}$ de peso vivo). Apenas os animais que receberam 10 vezes a dose recomendada apresentaram sinais clínicos. 0 exame histológico nos ovinos experimentais mostrou resultados 
semelhantes aos do surto, com exceção da ausência de fibrose e infiltrado inflamatório do nervo óptico, caracterizando um quadro agudo. Foram observadas a perda da bainha de mielina dos axônios e a presença de fibroblastos e fibras colágenas no estudo ultra-estrutural do nervo óptico de animais intoxicados espontaneamente. No nervo óptico de animais intoxicados experimentalmente havia vacúolos que separavam as bainhas de mielina dos axônios. Para evitar surtos, sugere-se pesar os animais antes da administração de Closantel para evitar erros no cálculo da dose.

TERMOS DE INDEXAÇÃO: Closantel, sobredosagem, intoxicação, cegueira, ovinos.

\section{INTRODUCTION}

Closantel is an antiparasitic drug belonging to the salicylanilide class used to control Haemonchus contortus, mature and immature forms of Fasciola hepatica and larvae of Oestrus ovis (Gill et al. 1999). This drug is toxic to many species, including dogs (McEntee et al. 1995), sheep and goats (Gill et al. 1999, Barlow et al. 2002, Van der Lugt \& Venter 2007, Ecco et al. 2008). A combination of Closantel and albendazole was also reported to be toxic for sheep and goats (Obwolo et al. 1989).

Accidental poisoning occurs when the drug is administered in amounts that are 2-6 times the recommended dose (Borges et al. 1999, Barlow et al. 2002). In all of these cases, the exact dose that induced intoxication was only estimated.

The clinical signs described in intoxicated sheep include lack of coordination, weakness, recumbency, mydriasis, blindness, walking in circles, depression, dark green diarrhea and death (Obwolo et al. 1989, Borges et al. 1999, Gill et al. 1999, Barlow et al. 2002).

The most important macroscopic findings are restricted to the ocular globe and central nervous system. When they are observable, they include brain inflammation and congestion (Borges et al. 1999) and narrowing of the intracanalicular and rostral segments of the optic nerve (Gill et al. 1999, Barlow et al. 2002). The microscopic findings include bilateral degenerative changes in the retina, with detachment of the pigment epithelium, loss of the photoreceptor cells and depletion of both outer and inner nuclear layers. Severe bilateral vacuolar degeneration of the intraorbital optic nerve, infiltration with Gitter cells and some perivascular cuffing may be observed (Barlow et al. 2002). Myelin edema in the optic nerve and optic tracts, with scattered foci of myelinic edema within the brainstem and cerebellar peduncles also was described (Gill et al. 1999).

The aim of this study was to describe the epidemiology, clinical signs, gross and histologic findings, and ultrastructural features of an outbreak of accidental Closantel poisoning in sheep and the experimental reproduction of the intoxication.

\section{MATERIALS AND METHODS}

Description of the outbreak. The Northwestern Regional Laboratory of DILAVE "Miguel C. Rubino" was consulted in reference to a case of collective neurological clinical signs in sheep. Epide- miological information was obtained through interviews with the veterinarian responsible for the case and visits to the farm. Five affected sheep were necropsied between 2 and 12 months after the onset of clinical signs. All organs, including the central nervous system, ocular bulb and optic nerve were fixed in $10 \%$ buffered formalin, embedded in paraffin, sectioned at $5 \mu \mathrm{m}$ and stained with haematoxylin and eosin.

Experimental reproduction. Five Corriedale crossbreed male sheep were used. These sheep were 6-year-old, castrated, with body weights (BW) between 37.5 and $44.5 \mathrm{~kg}$. The treatments performed are presented in Table 1 . Daily clinical examination was performed.

Between 5 and 10 minutes after the death of sheep 3 and 4, a necropsy was performed and material was collected, including the central nervous system, ocular bulb and optic nerve for histological and ultrastructural study.

Ultrastructural study. Two sheep of the accidental outbreak that presented chronic clinical signs of blindness eight months after the administration of Closantel were euthanized and necropsied. Small fragments of the central nervous system, ocular bulb and optic nerve were collected between 5 to 10 minutes after euthanasia and placed in a solution of $2 \%$ glutaraldehyde and $2 \%$ paraformaldehyde buffered with $0.4 \mathrm{M}$ cacodylate ( $\mathrm{pH} 7.4$ ). The tissues were subsequently fixed in osmium tetroxide $1 \%$ buffered in $0.4 \mathrm{M}$ sodium cacodylate ( $\mathrm{pH}$ 7.4). Lastly, they were placed in Epon 812. The sections of tissue were stained with methylene blue. Ultrathin sections were stained with lead citrate and uranyl acetate and were examined by electron microscope Zeiss EM 10 at $60 \mathrm{kV}$.

The same procedure was performed for the collection of material for ultrastructural study in the case of the experimentally intoxicated sheep 3 and 4.

\section{RESULTS}

\section{Description of the outbreak}

The outbreak occurred on a farm in Tacuarembó, Uruguay $\left(31^{\circ} 43^{\prime} 5.22^{\prime \prime} \mathrm{S}-55^{\circ} 59^{\prime} 6.93^{\prime \prime} 0\right)$ in 2011 . From a total of 1300 Corriedale sheep, 148 lambs (morbidity 14\%) presented neurological clinical signs twenty days after oral administration of $10 \%$ Closantel (January 2011). Fourteen lambs died from accidents secondary to the neurological signs such as blindness and lack of coordination. Clinical signs included mydriasis, nystagmus, negative papillary reflex to light, bilateral blindness, lateral movement of the head and bump into objects (Fig.1AB). The ataxia was intensified when the animals were moved.

No gross lesions were found in the necropsies performed on the five lambs. Microscopic lesions were mainly restricted to the retina, characterized by cytoplasmic vacuolization of ganglion cells and cells of the inner and

Table 1. Experimental reproduction: Identification of sheep, body weight and Closantel dose

\begin{tabular}{lccc}
\hline Sheep & Body weight (BW) $(\mathrm{kg})$ & Overdose* $^{*}$ & Dose $(\mathrm{g} / \mathrm{kg}$ of BW) \\
\hline 1 & 44.5 & 2.5 & 0.25 \\
2 & 39.5 & 4 & 0.40 \\
3 & 44.5 & 10 & 1 \\
4 & 37.5 & 10 & 1 \\
5 & 40.0 & 0 & 0
\end{tabular}

* Overdoses administered were 2.5, 4 and 10 times the therapeutic dose for sheep $(0.1 \mathrm{~g} / \mathrm{kg}$ of BW). 


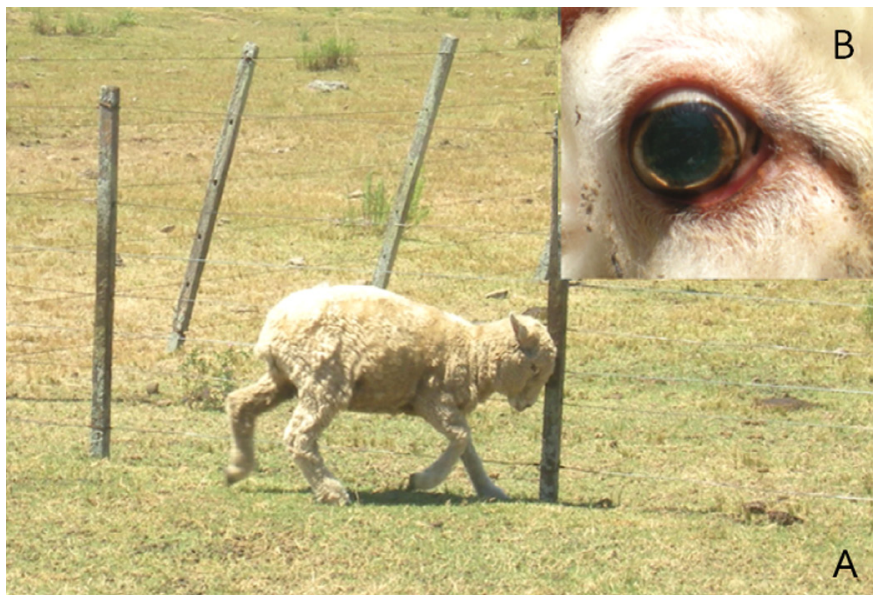

Fig.1. (A) Sheep accidentally intoxicated by Closantel bumping into a wire fence due to bilateral blindness. (B) Sheep with marked dilatation of the pupil (mydriasis). orbital portion and a lymphocytic monocytic (Gitter cells) infiltrate (Fig.3A and 3B).

\section{Experimental reproduction}

The clinical signs of the sheep during the experimental reproduction are shown in Table 2 . Sheep 1 and 2 had no clinical signs after administration of Closantel. In sheep 3, bilateral blindness with negative pupillary reflex to light was observed six days after Closantel administration. On day 9 , this sheep remained constantly recumbent, showing signs of anorexia and depression and was euthanized. Sheep 4 had after 72 hours of the administration of the medicine, signs of depression, anorexia, along with positive pupillary reflex and an abnormal posture with open forelimbs and closed pelvic limbs. Ninety-six hours after the Closantel administration, the animal was in deep depression, with bilateral blindness and negative pupillary reflex to light, dying a few hours later.

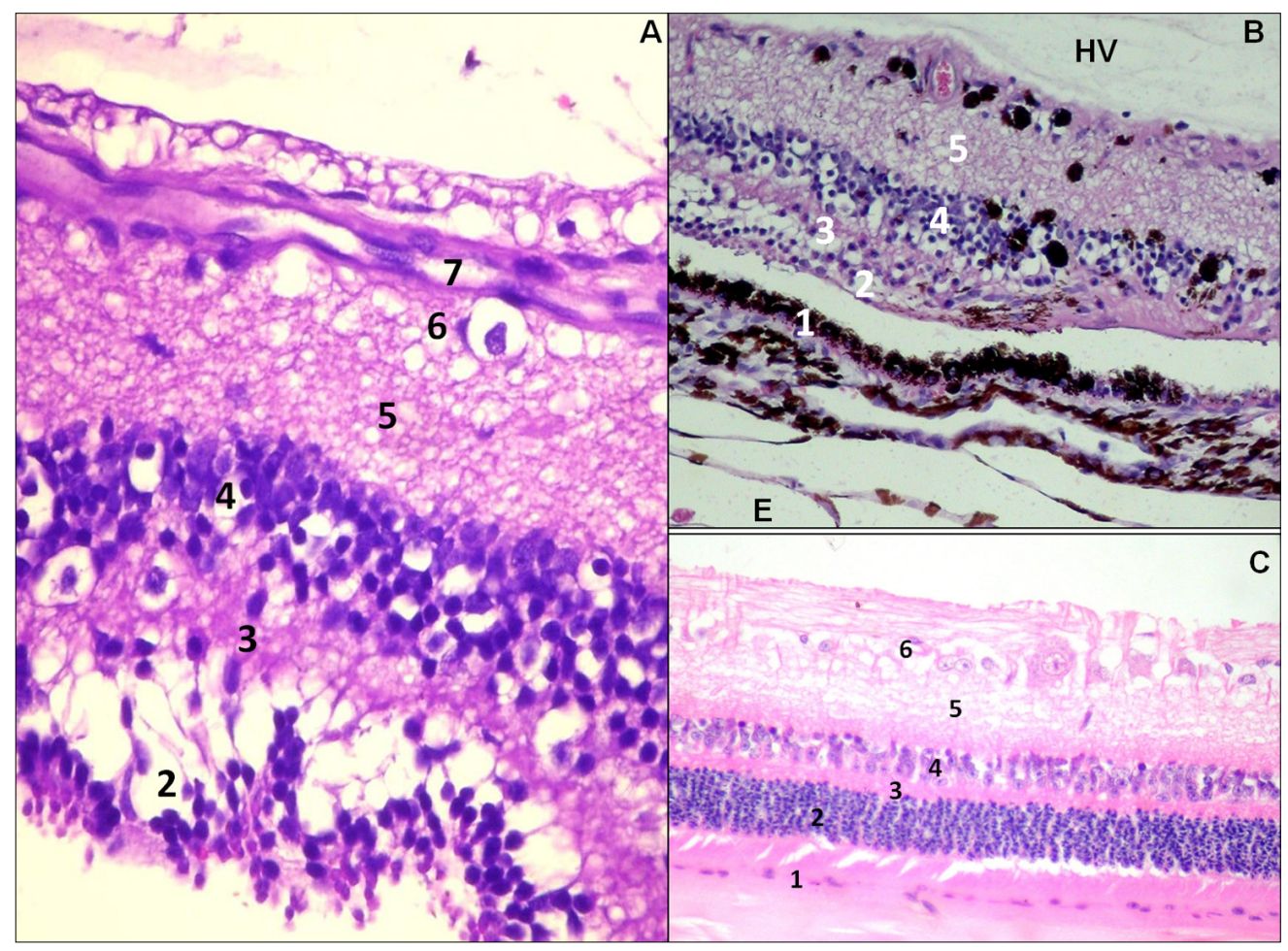

Fig.2. Sheep. Retina. Accidental Closantel outbreak. (A) Cytoplasmic vacuolization of ganglion cells and cells of the inner and outer nuclear layer. HE, obj. 40x. (B) Melanin pigment migration towards the inner region of the retina. HE, obj. 25x. (C) Retina: Negative control animal. HE, obj. 10x. *References: Pigmented epithelium (1), Outer nuclear layer (2), Outer plexiform layer (3), Inner nuclear layer (4), Inner plexiform layer (5), Ganglion cells (6), Layer of optic nerve fibers (7), $\mathrm{HV}=$ vitreous, $\mathrm{E}=$ sclera.

outer nuclear layer. The outer plexiform layer also showed vacuolization of the axons of the inner nuclear layer neurons (Fig.2A), associated with areas of pigmented epithelial hyperplasia and melanin pigment migration to the inner layers (Fig.2B). In the central nervous system, there was vacuolization (status spongiosus) of the white matter of the brain.

The optic nerve showed axonal degeneration (axonal vacuolization) with multifocal areas of fibrosis in the intra-

Fig.3. Sheep. Optical nerve. Accidental Closantel outbreak. (A) Cross section of the retrobulbar portion of the optic nerve. Fibroblast proliferation, neovascularization and Gitter cells (arrow). HE, obj.40x. (B) Infiltrate of lymphocytes and Gitter cells (arrow). HE, obj.40x.

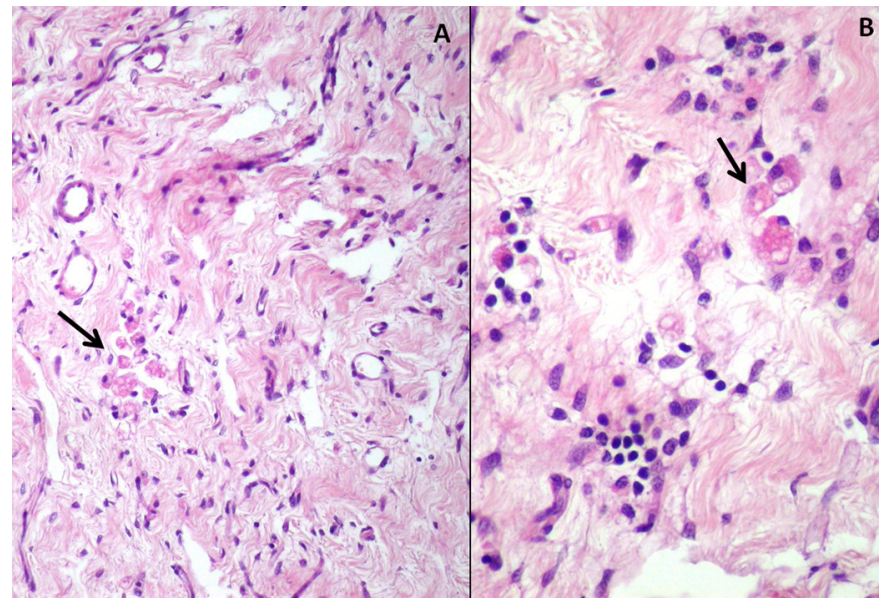


Table 2. Experimental reproduction: Closantel dose, clinical signs and evolution

\begin{tabular}{|c|c|c|c|c|c|c|c|c|}
\hline Sheep & $\begin{array}{l}\text { Closantel dose } \\
\text { (g/kg of BW) }\end{array}$ & Blindness & $\begin{array}{c}\text { Pupillary reflex } \\
\text { negative }\end{array}$ & Recumbence & Anorexia & Depression & $\begin{array}{l}\text { Onset of clinical } \\
\text { sign (days) }\end{array}$ & $\begin{array}{c}\text { al Clinical } \\
\text { course }\end{array}$ \\
\hline 1 & 0.25 & - & - & - & - & - & - & - \\
\hline 2 & 0.40 & - & - & - & - & - & - & - \\
\hline 3 & 1 & + & + & + & + & + & 6 & $\begin{array}{c}\text { Euthanized } \\
\text { (day 9) }\end{array}$ \\
\hline 4 & 1 & + & + & + & + & + & 2 & $\begin{array}{c}\text { Death } \\
\text { (day 4) }\end{array}$ \\
\hline 5 & 0 & - & - & - & - & - & - & - \\
\hline
\end{tabular}

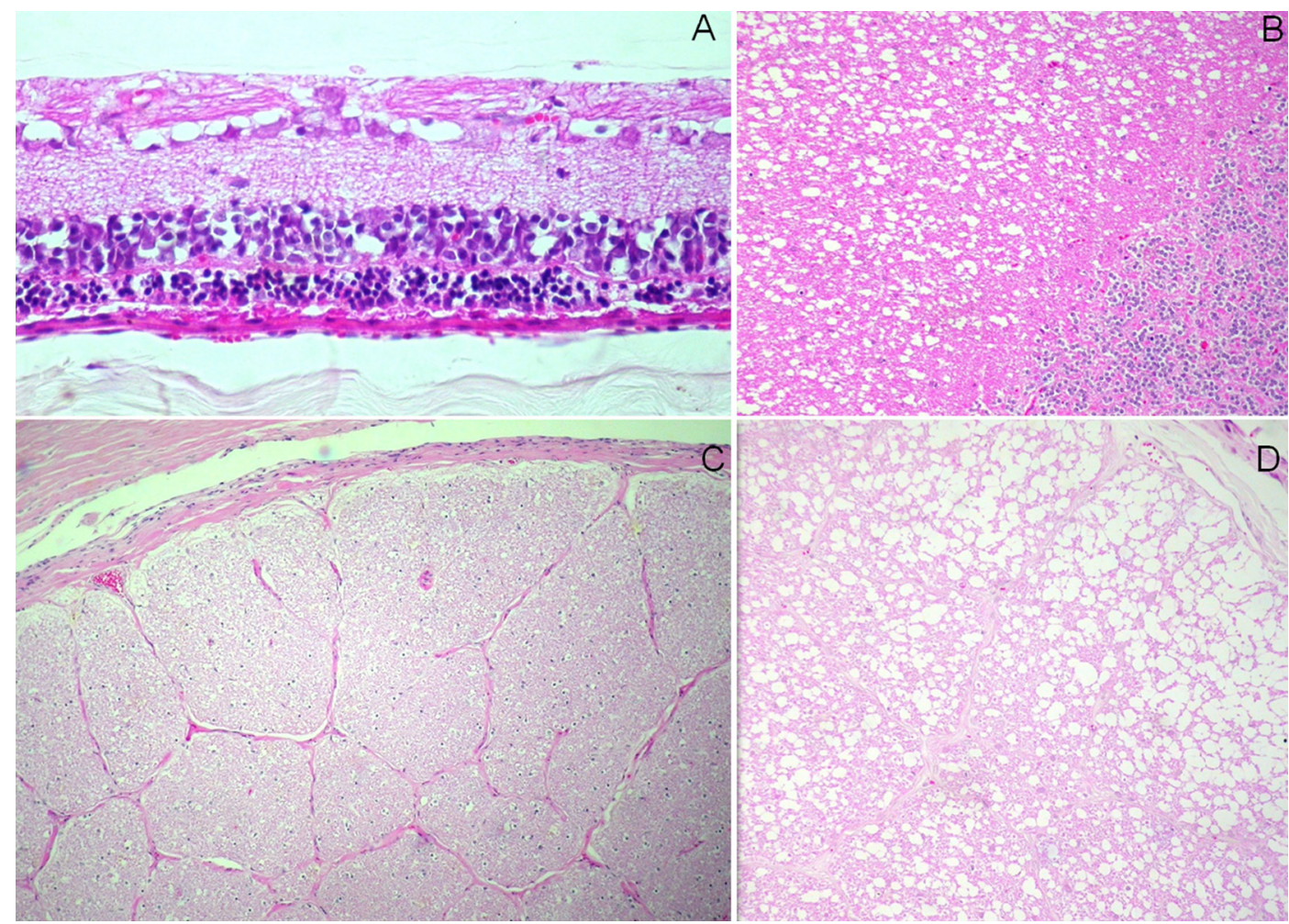

Fig.4. Sheep. Experimental reproduction of Closantel intoxication. (A) Sheep 3. Retina: cytoplasmic vacuolization of ganglion cells and cells of the inner and outer nuclear layer. HE, 200x. (B) Sheep 4. Cerebellum: vacuolization of the white matter. HE, obj. 40x. (C). Sheep 5. Optic nerve: negative control animal. HE, obj.20x. (D) Sheep 4. Optic nerve: vacuolization and axonal degeneration. HE, obj.40x.

Bilateral edema of the intracanalicular portion of the optic nerve was macroscopically observed only in sheep 4. The histological lesions were similar in the sheep 3 and 4. There was vacuolization of ganglion cells and the cells of the inner and outer plexiform layers of the retina (Fig. 4A). In the central nervous system, there was vacuolization of the white matter of the cerebellum and brainstem. Vacuolization and degeneration of axons was observed in the optic nerve (Fig.4B and 4D).

\section{Ultrastructural study}

In the optic nerve of accidental intoxicated sheep, most axons had lost their myelin sheath (demyelination). Fibroblasts and collagen fibers were also observed replacing axons (Fig.5).

The lesion at the optic chiasm was similar to that observed in the optic nerve (Fig.6), except for the lack of fibroblasts and collagen fibers.

In the experimental reproduction, the spongy areas in

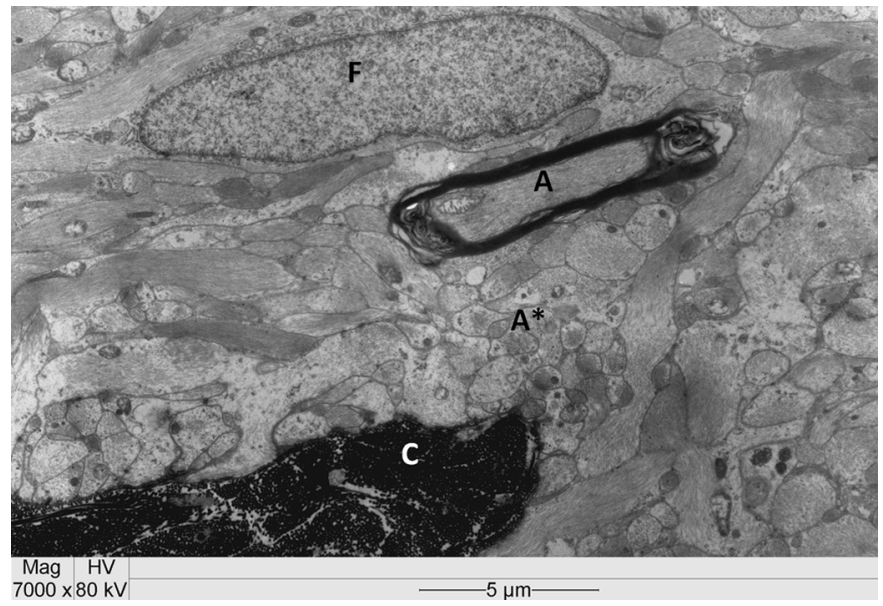

Fig.5. Sheep. Optical nerve. Accidental Closantel outbreak. (A*) Axons without myelin sheath, (A) axon with myelin sheath. The presence of fibroblast (F) and collagen fibers (C). Transmission electron microscopy. 


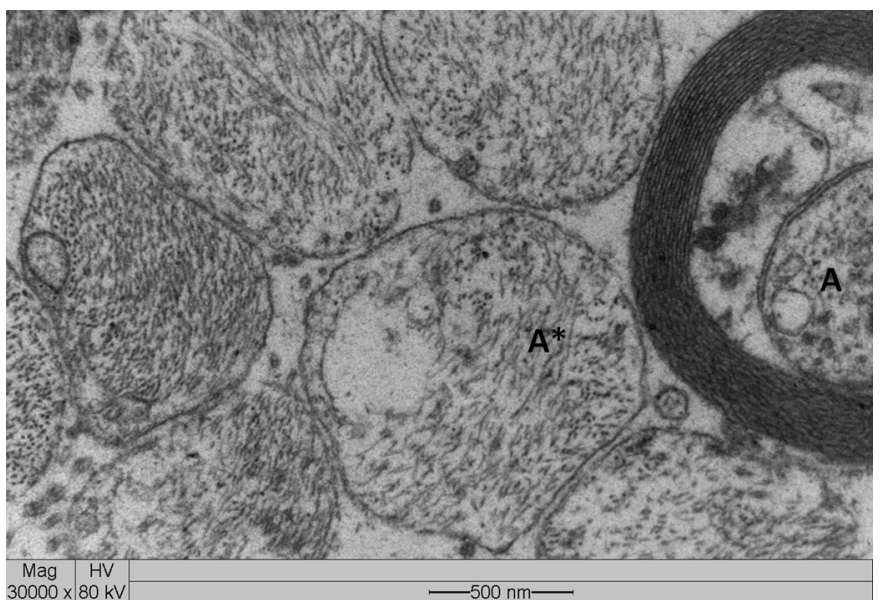

Fig.6. Sheep. Optic chiasm. Accidental Closantel outbreak. Swollen axons without myelin sheath $\left(\mathrm{A}^{*}\right)$ and a single axon with myelin sheath (A). Transmission electron microscopy.

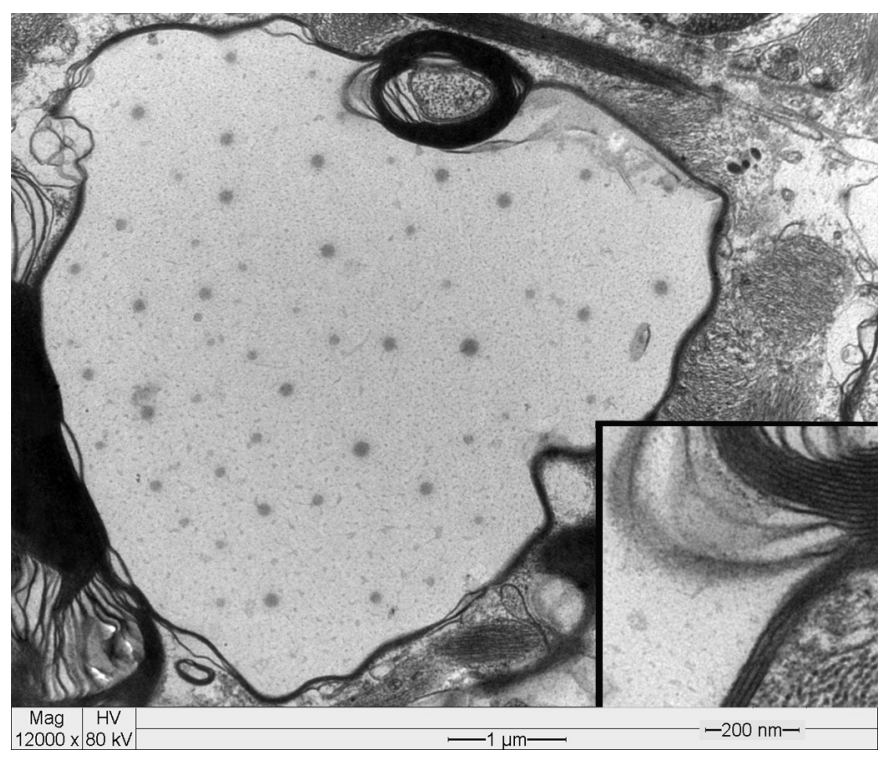

Fig.7. Sheep. Experimental reproduction of Closantel intoxication. Optic nerve. Axon with myelin layers separated by a large vacuole. Separation of the layers of myelin (detailed image). Transmission electron microscopy.

the optic nerve observed in the histological study corresponded to vacuoles that separated the myelin sheaths of axons (Fig.7). The vacuoles (single or multiple) were different sizes and empty. Axonal swelling was also observed.

\section{DISCUSSION}

The lesions observed in both accidental and experimental intoxication are similar to those reported in Closantel intoxication (Gill et al. 1999, Barlow et al. 2002, Van der Lugt $\&$ Venter 2007). The lesions were mainly restricted to the retina, optic nerve and white matter of the central nervous system. The clinical signs manifested by these sheep were related to the specific lesions found.

Accidental cases were defined as chronic because the main lesions in optic nerve and retina were registered between 2 and 12 months after onset of clinical signs. The histological lesions were atrophy of the retina, pigment epithelial hyperplasia and cell pigment migration. Same lesions have been reported by Van der Lugt \& Venter (2007) in sheep and goats 56-70 days after of administration of Closantel. Degeneration of the optic nerve, with proliferation of fibrous tissue, was also observed. Van der Lugt $\&$ Venter (2007) also described vacuolar degeneration of myelin and eventually irreversible fibrosis of the optic nerve with contraction.

The spongy appearance of the white matter of the brain and spinal cord was also reported in spontaneous cases by Furlan et al. (2009). The spongy status induced by Closantel in the central nervous system is due to the formation of vacuoles between the layers of myelin. This lesion is also observed as a result of intoxication by substances such as ammonia (Cho \& Leipold 1977) and copper (Morgan 1973), by ingestion of plants such as Stypandra imbricate (Huxtable et al. 1980, Main et al. 1981) and Helichrysum argyrosphaerum (Basson et al. 1975, Van der Lugt et al. 1996) or by ingestion of fungi such as Stenocarpella maydis (Kellerman et al. 1991, Prozesky et al. 1994). The physiopathology of the separation of myelin layers is not known (Van der Lugt \& Venter 2007). However, some authors report that oligodendrocyte death may play a role in the separation of myelin after administration of aniline in mice (Okazaki et al. 2001).

The retinopathy observed in Closantel poisoning, as well as in intoxication by Stypandra imbricata and Helichrysum argyrosphaerum, in sheep and goats occurs due to acute degenerative damage to the layers of the retina. These injuries would be a direct effect of the active substances and not a secondary effect of the optic nerve neuropathy (Gill et al. 1999).

Three possible causes have been suggested for the neuropathy induced by Closantel (Van der Lugt \& Venter 2007), Stypandra imbricate (Huxtable et al. 1980) and Helichrysum argyrosphaerum (Van der Lugt et al. 1996). These would be the direct effect on axons, edematous nerve compression within the optical channel, or a combination of both causes (Huxtable et al. 1980).

According to the literature, blindness is the primary clinical sign presented in animals intoxicated by Closantel as observed in the outbreak presented here, followed in some cases by ataxia and the death of some animals (Gill et al. 1999, Barlow et al. 2002, Van der Lugt \& Venter 2007, Ecco et al. 2008, Furlan et al. 2009). In this accidental case, there were no deaths in the affected sheep probably because of the acute intoxication, consistent with findings by other authors (Borges et al. 1999, Gill et al. 1999, Furlan et al. 2009); this could be related to the dose utilized. The deaths that occurred were secondary accidents due to the blindness and the lack of coordination of the animals.

It was not possible to identify the toxic dose that caused cases of accidental intoxication. The recommended Closantel dose for sheep is $0.1 \mathrm{~g} / \mathrm{kg}$ of BW (Radostits et al. 2007). In some reports of intoxication, it has been estimated that the overdose sufficient to produce clinical signs must have been 3 to 6 times more the therapeutic dose (Borges et al. 1999) and, in other reports, 2 to 5 times more the thera- 
peutic dose (Barlow et al. 2002). It is presumed that the dose error in the outbreak could have occurred because adult sheep (average $40 \mathrm{~kg}$ of BW) were dosed together with lambs (average $15 \mathrm{~kg}$ of BW) and the adult dose was administered in both cases. The fact that adult animals were not affected reinforces this idea. In other reports of Closantel-related poisonings, young animals, especially those younger than one year, are the main affected category (Van der Lugt et al. 1996, Borges et al. 1999, Barlow et al. 2002, Furlan et al. 2009).

Differential diagnoses of blindness in sheep should be undertaken in relation to other drugs such as rafoxanide (Prozesky \& Pienaar 1977). Other diseases, such polioencephalomalacia as a result of vitamin B1 deficiency and lead poisoning, also induce blindness, causing a characteristic laminar cortical necrosis of the gray matter. Other diseases that can also cause neurological clinical signs should also be differentiated, such as Listeria monocytogenes infection, Coenurus cerebralis, Visna virus infection, rabies, intoxication by Halimium brasiliense, toxemia of pregnancy in ewes and intoxication by Ramaria flavo-brunnescens (Riet-Correa \& Méndez 2007, van der Lugt et al. 1996). All of these diseases have a particular epidemiology as well as gross and microscopic lesions that distinguish them from Closantel intoxication, with the exception of rafoxanide that could be confused. It is critical to send the ocular bulb, optic nerve and central nervous system to the laboratory for proper diagnosis of this type of intoxication.

In this outbreak, the epidemiology, clinical signs, gross and microscopic findings confirm the diagnosis of intoxication by Closantel. It is recommended that, prior to the administration of this anthelmintic drug, maximum and minimum weight must be determined, especially in young animals. They should be dosed in small group sizes based on body weight to avoid dosing errors.

\section{REFERENCES}

Barlow A.M., Sharpe J.A.E. \& Kincaid E.A. 2002. Blindness in lambs due to inadvertent closantel overdose. Vet. Rec. 151:25-26.

Basson P.A., Kellerman T.S., Albl P., Von Maltitz L.J., Miller E.S. \& Welman W.G. 1975. Blindness and encephalopathy caused by Helichrysum argyrosphaerum DC. (Compositae) in sheep and cattle. Onderstepoort J. Vet. Res. 42(4):135-147.

Borges A.S., Mendes C.N., Andrade A.L., Machado G.F. \& Peiro J.R. 1999. Optic neutropathy in sheep associated with overdosage of closantel. Vet. Human Toxicol. 41(6):378-380.
Cho D.Y. \& Leipold H.W. 1977. Experimental spongy degeneration in calves. Acta Neuropathol (Berl.). 39:115-127.

Ecco R., Barros C.S.L. \& Graça D.L. 2008. Alterações oftálmicas associadas à intoxicação experimental por closantel em caprinos [Ophtalmic changes associated with the experimental poisoning by closantel in caprine]. Arq. Bras. Med. Vet. Zootec. 60(1):42-50.

Furlan F.H., Lucioli J., Borelli V., Fonteque J.H., Stolf L., Traverso S.D. \& Gava A. 2009. Intoxicação por closantel em ovinos e caprinos no Estado de Santa Catarina [Poisoning by closantel in sheep and goats in the State of Santa Catarina, Brazil]. Pesq. Vet. Bras. 29(1):89-93.

Gill P.A., Cook R.W., Boulton J.G., Kelly W.R., Vanselow B. \& Reddacliff L.A. 1999. Optic neuropathy and retinopathy in closantel toxicosis of sheep and goats. Aust. Vet. J. 77(4):259-261.

Huxtable C.R., Dorling P.R. \& Slatter D.H. 1980. Myelin oedema, optic neuropathy and retinopathy in experimental Stypandra imbricata toxicosis. Neuropathol. Appl. Neurobiol. 6(3):221-232.

Kellerman T.S., Prozesky L., Schultz R.A., Rabie C.J., van Ark H., Maartens B.P. \& Lübben A. 1991. Perinatal mortality in lambs of ewes exposed to cultures of Diplodia maydis (= Stenocarpella maydis) during gestation. Onderstepoort J. Vet. Res. 58:297-308.

Main D.C., Slatter D.H., Huxtable C.R., Constable I.C. \& Dorling P.R. 1981. Stypandra imbricata ("blindgrass") toxicosis in goats and sheep clinical and pathologic findings in 4 field cases. Aust. Vet. J. 57(3):132-135.

McEntee K., Grauwels M., Clerex C. \& Henroteaux M. 1995. Closantel intoxication in a dog. Vet. Human Toxicol. 37:234-236.

Morgan K.T. 1973. Chronic copper toxicity of sheep: an ultrastructural study of spongiform leucoencephalopathy. Res. Vet. Sci. 15:88-95.

Obwolo M.J., Odiawo G.O. \& Ogaa J.S. 1989. Toxicity of a closantel-albendazole mixture in a flock of sheep and goats. Aust. Vet. J. 66(7):229-230.

Okazaki Y., Yamashita K., Sudo M., Tsuchitani M., Narama I., Yamaguchi R. \& Tateyama S. 2001. The progression and recovery of neurotoxicity induced by a single oral dose of aniline in rats. J. Toxicol. Pathol. 14:19-28.

Prozesky L., Kellerman T.S., Swart D.P., Maartens B.P. \& Schultz R.A. 1994. Perinatal mortality in lambs of ewes exposed to cultures of Diplodia maydis (= Stenocarpella maydis) during gestation. A study of the central nervous system lesions. Onderstepoort. J. Vet. Res. 61(3):247-253.

Prozesky L. \& Pienaar J.G. 1977. Amaurosis in sheep resulting from treatment with rafoxanide. Onderstepoort. J. Vet. Res. 44(4):257-260.

Radostits O.M., Gay C.C., Hinchcliff P.D. \& Constable P.D. 2007. Veterinary Medicine. 10th ed. Saunders Elsever, Spain. 2156p.

Riet-Correa F. \& Méndez M.C. 2007. Plantas e micotoxinas que afetam a pele e outros órgãos [Plant and mycotoxins that affect the skin and other organs], p.206-209. In: Riet-Correa F., Schild A.L., Lemos R. \& Borges J.R.J. (Eds), Doenças de ruminantes e equídeos [Diseases of ruminants and equines]. $3^{3}$ ed. Editorial Palotti, Brasil.

Van der Lugt J.J., Olivier J. \& Jordain P. 1996. Status spongiosis, optic neuropathy, and retinal degeneration in Helichrysum argyrosphaerum poisoning in sheep and a goat. Vet. Pathol. 33:495-502.

Van der Lugt J.J. \& Venter I. 2007. Myelin vacuolation, optic neuropathy and retinal degeneration after closantel overdosage in sheep and in a goat. J. Comp. Pathol. 136:87-95. 